\title{
Reclassification of Paenibacillus durum (Formerly Clostridium durum Smith and Cato 1974) Collins et al. 1994 as a Member of the Species $P$. azotofixans (Formerly Bacillus azotofixans Seldin et al. 1984) Ash et al. 1994
}

\author{
A. S. ROSADO,,$^{1,2}$ J. D. VAN ELSAS, ${ }^{2}$ AND L. SELDIN ${ }^{1 *}$ \\ Instituto de Microbiologia, Universidade Federal do Rio de Janeiro, Centro de Ciencias da Saúde, Bloco I, \\ Ilha do Fundão, Rio de Janeiro, 21941-590 RJ, Brazil, ${ }^{1}$ and DLO-Research Institute for Plant Protection, \\ $6700 \mathrm{GW}$ Wageningen, The Netherlands ${ }^{2}$
}

\begin{abstract}
Phenotypic studies, as well as the reaction of Paenibacillus durum genomic DNA with a 16S ribosomal DNA (sequence of variable regions V1 to V4)-based Paenibacillus azotofixans-specific PCR system and oligonucleotide probe, the presence of sequences homologous to Klebsiella pneumoniae nifKDH in both $P$. durum and $P$. azotofixans, and the results of DNA-DNA hybridization experiments performed with the $P$. durum and $P$. azotofixans type strains and one additional $P$. durum strain, showed that these two species form a homogeneous group. In addition, evidence was found for the presence of nif genes in $P$. durum, and $P$. durum was shown to fix atmospheric nitrogen. Therefore, the names $P$. durum and $P$. azotofixans should be considered synonyms. As $P$. durum was capable of fixing nitrogen and fixation without inhibition by nitrate is a major characteristic of the group, we propose that $P$. durum be included in the species $P$. azotofixans.
\end{abstract}

In 1974, a new species named Clostridium durum was described by Smith and Cato (11) as the dominant organism in a sediment core from the Black Sea. All of the isolates in this study formed a homogeneous group and had similar properties, and strain VPI 6563 was deposited as the type strain in the American Type Culture Collection as strain ATCC 27763. These organisms have characteristics which are atypical for clostridia, such as, for example, their inability to grow on egg yolk agar, their production of acetic and formic acids, and their inability to ferment lactose. Moreover, the guanine-plus-cytosine $(\mathrm{G}+\mathrm{C})$ content of the DNA of $C$. durum $(50 \mathrm{~mol} \%)$ was higher than the $\mathrm{G}+\mathrm{C}$ contents of other clostridia (11). Actually, the strains were considered members of the genus Clostridium because of their ability to form spores under anaerobic conditions. Smith and Cato considered this criterion the only reliable criterion for separating the genus Clostridium from the genus Bacillus.

In 1994, Collins et al. (3), after studying the phylogeny of the genus Clostridium, proposed five new genera and 11 new species. It was evident from the data of these authors that $C$. $d u$ rum is only remotely related to other clostridia. Phylogenetically, $C$. durum was considered a member of the newly formed genus Paenibacillus (1). This genus comprises rRNA group 3 of Ash et al. (1), which also includes the nitrogen-fixing species Paenibacillus azotofixans, Paenibacillus polymyxa, and Paenibacillus macerans. Based on the studies of Collins et al. (3), it was concluded that $P$. durum is closely related to $P$. azotofixans; the level of similarity of the $16 \mathrm{~S}$ rRNAs of these organisms is approximately $98 \%$.

The taxon $P$. azotofixans includes strains that are often isolated from the rhizospheres of different grasses $(6,8,10)$ and consistently show a great capacity to fix atmospheric nitrogen in vitro (6). These strains are facultatively anaerobic, catalase positive, oxidase negative, and positive for acetoin fermenta-

\footnotetext{
* Corresponding author. Mailing address: Instituto de Microbiologia, UFRJ, CCS, Bloco I, Ilha do Fundão, CEP 21941-590, Rio de Janeiro RJ, Brazil. Phone: 005521590 3093. Fax: 0055212599957. E-mail: IMMGSEL@microbio.ufrj.br.
}

tion (Voges-Proskauer test) (4). Their $\mathrm{G}+\mathrm{C}$ contents vary from 47.9 to $52.5 \mathrm{~mol} \%$ (6), and they exhibit low levels of DNA-DNA homology (less than 18\%) (7) with the most closely related species, $P$. polymyxa. Testing $P$. azotofixans strains with API 50CH kits (Appareils et Procédés d'Identification; API-bioMerieux, Marcy l'Etoile, France) showed that they all produce acid from galactose, $\mathrm{D}$-glucose, $\mathrm{D}$-fructose, $\mathrm{D}$-mannose, mannitol, $\alpha$-methylglucoside, esculin, maltose, melibiose, sucrose, trehalose, melezitose, D-raffinose, $\beta$-gentiobiose, and D-turanose. Furthermore, 18 carbohydrates (glycerol, erythritol, D-arabinose, L-arabinose, ribose, D-xylose, L-xylose, adonitol, $\beta$-methylxyloside, L-sorbose, rhamnose, inositol, lactose, xylitol, D-lyxose, D-fucose, L-fucose, and L-arabitol) were not utilized by any strain tested. Six of the remaining carbohydrates, sorbitol, dulcitol, tagatose, starch, glycogen, and D-arabitol, can be used to divide $P$. azotofixans strains into five groups (8).

Recently, Rosado et al. (5) developed a molecular method for detection of $P$. azotofixans in soil. The system consists of PCR amplification of part of variable regions V1 to V4 of the 16S rRNA gene, followed by hybridization with a specific 18-bp oligonucleotide probe homologous to part of the intervening region. In vitro specificity tests showed that this combined detection system was specific for $P$. azotofixans strains and that no other Paenibacillus species or species of the other bacterial genera studied was detected. Finally, DNAs from all of the $P$. azotofixans strains studied were shown to exhibit homology to Klebsiella pneumoniae nifKDH genes (2) in Southern hybridization experiments. More than one hybridizing fragment was obtained in Eco RI genomic DNA digests of all of the strains, resulting in 14 different hybridization patterns. In $66.2 \%$ of the strains, a $4.1-\mathrm{kb}$ fragment hybridized with the structural nitrogenase genes (9; unpublished data).

Using this description of $P$. azotofixans, we decided to compare two available $P$. durum strains (ATCC $27763^{\mathrm{T}}[\mathrm{T}=$ type strain] and ATCC 27812) with $P$. azotofixans type strain ATCC 35681 (= P3L5), as well as other Paenibacillus strains, to analyze the relatedness of the two species. Experiments were carried out by using a $K$. pneumoniae nifKDH probe, the $16 \mathrm{~S}$ rRNA-specific probe for $P$. azotofixans (BAZOP), the API test 
TABLE 1. Bacterial strains used in this study

\begin{tabular}{|c|c|}
\hline Strain & Source and other information \\
\hline \multicolumn{2}{|c|}{ Paenibacillus azotofixans strains } \\
\hline \multicolumn{2}{|c|}{ P3L5 ${ }^{\mathrm{T}}\left(=\right.$ ATCC $\left.35681^{\mathrm{T}}\right)$, P3E20 ..........................Wheat roots, Paraná, Brazil; described by Seldin et al. (6) } \\
\hline \multicolumn{2}{|c|}{ 2RC1, 2RC4 ............................................................... Sugarcane roots, Rio de Janeiro, Brazil; described by Seldin (10) } \\
\hline \multicolumn{2}{|c|}{ C3L4 ..................................................................... Sugarcane roots, Hawaii; described by Seldin and Penido (8) } \\
\hline \multicolumn{2}{|c|}{ Paenibacillus durum strains } \\
\hline \multicolumn{2}{|c|}{ ATCC $27763^{\mathrm{T}}$ (= DSM $1735^{\mathrm{T}}$ ) …........................... } \\
\hline \multicolumn{2}{|c|}{ 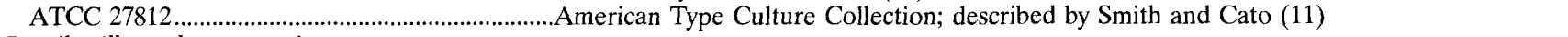 } \\
\hline \multicolumn{2}{|c|}{ Paenibacillus polymyxa strains } \\
\hline \multicolumn{2}{|c|}{ 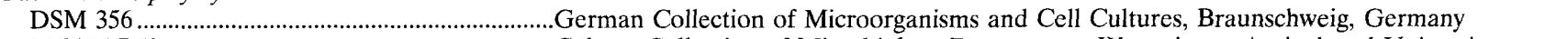 } \\
\hline \multicolumn{2}{|c|}{ LMAU B58...................................................... Culture Collection of Microbiology Department, Wageningen Agricultural University, } \\
\hline Escherichia coli $\mathrm{K}-12 .$. & .....Host of plasmid pSA30; received from F. Ausubel, Massachusetts General Hospital, Bo \\
\hline
\end{tabular}

system, and DNA-DNA hybridization to determine the levels of homology between the genomes of the $P$. azotofixans and $P$. durum type strains, as well as the genome of $P$. durum ATCC 27812.

All of the strains used in this study are listed in Table 1. Maintenance and propagation of cultures have been described previously $(6,7,9)$. Analyses of phenotypic features other than those analyzed by the API system were performed as described by Gordon et al. (4). Much like $P$. azotofixans, both $P$. durum strains sporulated under aerobic and anaerobic conditions, producing oval to ellipsoidal spores that were located centrally to subterminally and distended the sporangia (6). As proposed by Smith and Cato (11), P. durum might form spores at the bottom of colonies, where anaerobic conditions prevail; all $P$. azotofixans strains tested (6) also formed spores when they were incubated under anaerobic conditions (GasPak jars filled with $80 \% \mathrm{~N}_{2}-10 \% \mathrm{H}_{2}-10 \% \mathrm{CO}_{2}$ ). Hence, this criterion for separating aerobic spore-forming rods from anaerobic sporeforming rods is questionable. Moreover, acetoin fermentation was observed in both species. The following tests were negative for both species: gelatin, casein, urease, and indole. Catalase production was also observed in both $P$. durum and $P$. azotofixans. Furthermore, both $P$. durum strains and the $P$. azotofixans strains produced acid from the same 15 carbohydrates of the API 50CH test kit. The results obtained with the six carbohydrates which were used to group the $P$. azotofixans strains (sorbitol, dulcitol, tagatose, starch, glycogen, and D-arabitol) placed $P$. durum ATCC $27763^{\mathrm{T}}$ and ATCC 27812 in P. azotofixans group 3 (starch and glycogen positive) (8). The remaining carbohydrates produced the same pattern of fermentation as that described for $P$. azotofixans (8).

Three genetic approaches were used to confirm the similarity between $P$. durum and $P$. azotofixans. Rosado et al. (5) described two specific primers (BAZO 1 and BAZO 2) and a specific probe (BAZOP) based on three variable regions of the 16S rRNA sequence of $P$. azotofixans, as determined by Ash et al. (1). The PCR product generated with the target strain, $P$. azotofixans ATCC $35681^{\mathrm{T}}$, as well as with all of the other $P$. azotofixans strains tested, was 565 bp long and could be specifically detected by an 18-mer probe (5). Figure 1 shows the products generated by primers BAZO 1 and BAZO 2 and specific hybridization of a Southern blot of the PCR products (5) with probe BAZOP. Figure 1 shows that the $P$. durum type strain sequence was recognized by the primers and the probe, much like a $P$. azotofixans strain. Moreover, a stronger hybridization signal with probe BAZOP was obtained for the $P$. durum PCR product than for well-characterized $P$. azotofixans strains C3L4 and 2RC4 (Fig. 1). A similar PCR prod- uct was obtained with the other $P$. durum strain, ATCC 27812 (data not shown).

The second genetic aspect considered was the presence of sequences homologous to the prototype nifKDH genes (cloned from $K$. pneumoniae on plasmid pSA30). All P. azotofixans strains studied so far show homology at high stringency to nifKDH, and more than one hybridizing fragment is always obtained (9). Genomic DNA was isolated and digested with EcoRI as previously described (9). Figure 2 shows the hybrid-
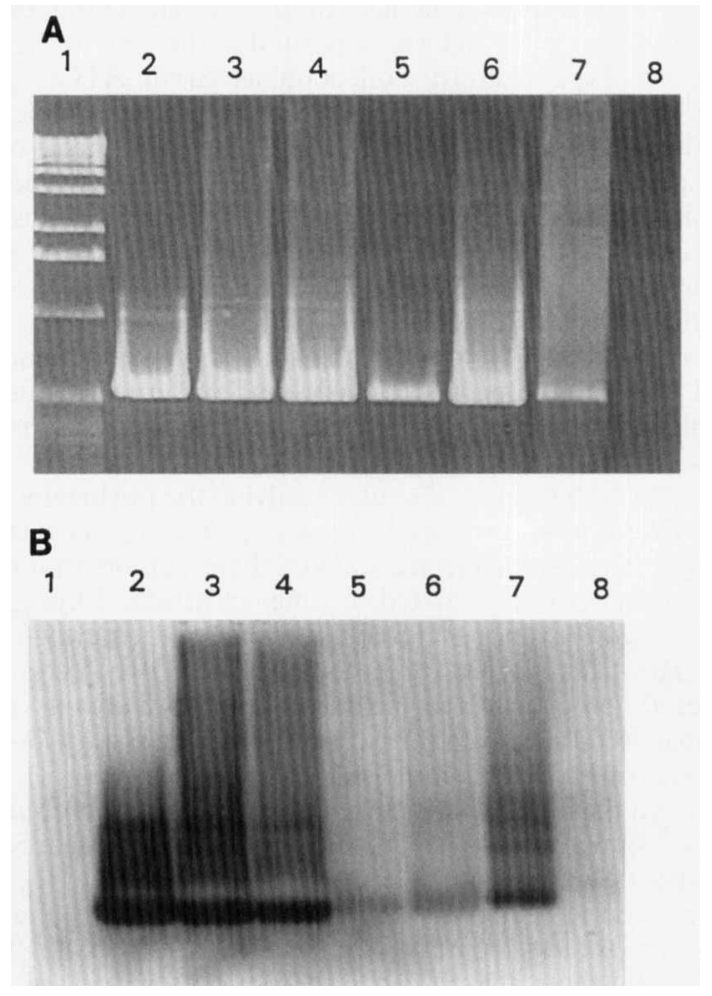

FIG. 1. Amplification of the 565-bp P. azotofixans-specific region by using 16S rRNA gene-targeted primers BAZO 1 and BAZO 2 together with hybridization with specific oligonucleotide probe BAZOP. (A) PCR products analyzed by agarose $(1.2 \%$, wt/vol) gel electrophoresis. Lane 1, ladder DNA (Gibco); lanes 2 through 6, P. azotofixans strains (lane 2, ATCC $35681^{\mathrm{T}}$; lane 3, P3E20; lane 4, 2RC1; lane 5, C3L4; lane 6, 2RC4); lane 7, P. durum ATCC $27763^{\mathrm{T}}$; lane 8 negative control (PCR without added DNA). (B) Southern blot analysis of the gel shown in panel A, hybridized with digoxigenin-labelled oligonucleotide probe BAZOP. 


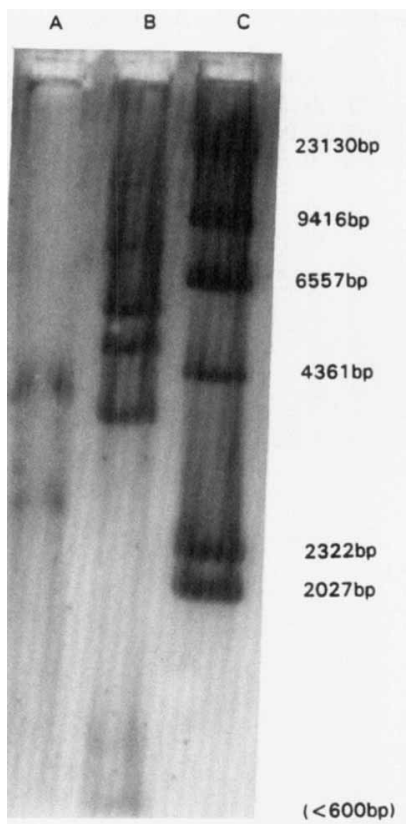

FIG. 2. Southern hybridization of DNAs from $P$. azotofixans ATCC $35681^{\mathrm{T}}$ and $P$. durum ATCC $27763^{\mathrm{T}}$ with a $K$. pneumoniae nifKDH (pSA30) probe. Both DNAs were digested with $E c o$ RI prior to agarose $(0.8 \%$, wt $/ \mathrm{vol})$ gel electrophoresis and Southern hybridization with digoxigenin-labelled pSA30 DNA. Lane A, $P$. azotofixans ATCC $35681^{\mathrm{T}}$; lane B, $P$. durum ATCC $27763^{\mathrm{T}}$; lane C, lambda HindIII digoxigenin-labelled ladder (BMB). The vector sequences present in probe pSA30 did not hybridize with $P$. azotofixans genomic DNA (9).

ization patterns observed with DNAs from $P$. azotofixans ATCC $35681^{\mathrm{T}}$ and $P$. durum ATCC $27763^{\mathrm{T}}$. $P$. durum ATCC $27763^{\mathrm{T}}$ thus has the genetic potential to fix atmospheric nitrogen, like $P$. azotofixans. However, the hybridization pattern of ATCC $27763^{\mathrm{T}}$ is different from any of the patterns obtained with $P$. azotofixans strains so far. Whereas incomplete digestion may explain the bands at high molecular weights, at least three strong bands and two weak bands represent fully digested $P$. durum genomic DNA fragments that contain nif $K D H$-homologous sequences (Fig. 2). Furthermore, P. dunum ATCC $27763^{\mathrm{T}}$ was recently shown to reduce acetylene, which suggests that it contains a functional nitrogenase (data not shown).

Finally, the levels of homology between genomic DNAs of the two $P$. durum strains and the $P$. azotofixans type strain were determined. The DNA concentrations used were the same, as determined by using a Gene Quant apparatus (Pharmacia). Serial twofold dilutions of genomic DNAs of both type strains ( $P$. azotofixans ATCC 35681 and $P$. durum ATCC 27763), $P$. durum ATCC 27812, and $P$. polymyxa DSM 356 and LMAU B58 were blotted by using a model SRC96D minifold I dot blotter (Schleicher \& Schuell) as recommended by the manufacturer. Genomic DNAs of $P$. azotofixans ATCC $35681^{\mathrm{T}}$ and $P$. durum ATCC $27763^{\mathrm{T}}$ and ATCC 27812 were labelled with digoxigenin-11-dUTP as recommended by the manufacturer (Boehringer Mannheim Biochemicals [BMB]) and used as probes. Dot blot hybridization was carried out as previously described (7). After hybridization, the blots were subjected to stringent washing steps, after which a chemiluminescence detection kit based on CSPD (catalog no. 1655/884; BMB) was used. Table 2 shows the relatedness of the genomic DNAs of the strains tested. The levels of DNA relatedness between the type strains of $P$. azotofixans and $P$. durum, as well as within $P$. durum ATCC 27812, ranged from 69 to $85 \%$, while $P$. polymyxa DSM 356 and LMAU B58 showed less than $25 \%$ relatedness
TABLE 2. Levels of DNA relatedness of $P$. azotofixans, $P$. durum, and $P$. polymyxa strains

\begin{tabular}{lccc}
\hline & \multicolumn{3}{c}{$\begin{array}{c}\text { \% Homology with DNAs from } \\
\text { the following probes }\end{array}$} \\
\cline { 2 - 4 } (target DNA) & $\begin{array}{c}\text { P. azotofixans } \\
\text { ATCC 35681 }\end{array}$ & $\begin{array}{c}\text { P. durum } \\
\text { DSM 1735 }\end{array}$ & $\begin{array}{c}\text { P. durum } \\
\text { ATCC 27812 }\end{array}$ \\
\hline $\begin{array}{l}\text { P. azotofixans ATCC 35681 } \\
\text { P. durum strains }\end{array}$ & 100 & 76 & 74 \\
$\quad \begin{array}{l}\text { DSM 1735 } \\
\text { ATCC 27812 }\end{array}$ & 69 & 100 & 81.5 \\
P. polymyxa strains & 78.3 & 85 & 100 \\
DSM 356 & 16 & 14 & 9 \\
LMAU B58 & 23 & 19.5 & 21.5 \\
\hline
\end{tabular}

${ }^{a}$ Values are the averages of two determinations. The maximum variation observed was $9 \%$.

with any of the three probes used. There were no great differences between the levels of homology measured when the genomic DNAs were used as targets or as probes. The levels of homology were determined by scanning the dot intensities with an LKB-Ultroscan XL instrument (Pharmacia). The peak areas were integrated and analyzed by using the software Gel Scan XL. The self-hybridization values were set at $100 \%$, and the values obtained with the other strains were compared to this standard.

As demonstrated in this paper, we could not find significant differences to justify separation of the $P$. durum strains used (including the type strain) from the $P$. azotofixans strains used. When the genus Paenibacillus was proposed (1), P. azotofixans (formerly Bacillus azotofixans) was already in group 3 of Ash et al. (1), whereas $P$. durum (formerly $C$. durum) was included later in this genus (3). Many current isolates of $P$. azotofixans are from the rhizospheres of very different crop plants, and these strains invariably show a high capacity to fix atmospheric nitrogen $(6,8,10)$. Therefore, we propose that the nitrogenfixing species $P$. durum should be included in $P$. azotofixans and that $P$. durum should be eliminated as a separate species.

This work was supported by a grant from the National Research Council of Brazil, as well as by a grant from the EU-IC program. A scholarship was awarded to A.S.R. by the National Research Counci of Brazil

We are grateful to A. C. Wolters for assistance with the Ultroscan XL machine and to G. F. Duarte for reviewing a draft of the manuscript.

\section{REFERENCES}

1. Ash, C., F. G. Priest, and M. D. Collins. 1993. Molecular identification of rRNA group 3 bacilli (Ash, Farrow, Wallbanks and Collins) using a PCR probe test. Proposal for the creation of a new genus Paenibacillus. Antonie van Leeuwenhoek 64:253-260.

2. Cannon, F. C., G. E. Riedel, and F. M. Ausubel. 1979. Overlapping sequences of Klebsiella pneumoniae nif DNA cloned and characterized. Mol. Gen. Genet. 174:59-66.

3. Collins, M. D., P. A. Lawson, A. Willems, J. J. Cordoba, J. FernandezGarayzabal, P. Garcia, J. Cai, H. Hippe, and J. A. E. Farrow. 1994. The phylogeny of the genus Clostridium: proposal of five new genera and eleven new species combinations. Int. J. Syst. Bacteriol. 44:812-826.

4. Gordon, R. E., W. C. Haynes, and H. N. Pang. 1973. The genus Bacillus. Agriculture Handbook no. 427. Agricultural Research Service, U.S. Department of Agriculture, Washington, D.C.

5. Rosado, A. S., L. Seldin, A. C. Wolters, and J. D. van Elsas. 1996. Quantitative $16 \mathrm{~S}$ rDNA targeted polymerase chain reaction and oligonucleotide hybridization for the detection of Paenibacillus azotofixans in soil and the wheat rhizosphere. FEMS Microbiol. Ecol. 19:153-164.

6. Seldin, L., J. D. van Elsas, and E. G. C. Penido. 1984. Bacillus azotofixans sp nov., a nitrogen-fixing species from Brazilian soils and grass roots. Int. J. Syst. Bacteriol. 34:451-456.

7. Seldin, L., and D. Dubnau. 1985. Deoxyribonucleic acid homology among 
Bacillus polymyxa, Bacillus macerans, Bacillus azotofixans, and other nitrogen-fixing Bacillus strains. Int. J. Syst. Bacteriol. 35:151-154.

8. Seldin, L., and E. G. C. Penido. 1986. Identification of Bacillus azotofixan using API tests. Antonie van Leeuwenhoek 52:403-409.

9. Seldin, L., M. C. F. Bastos, and E. G. C. Penido. 1989. Identification of Bacillus azotofixans nitrogen fixation genes using heterologous nif probes, $\mathrm{p}$ 179-187. In F. A. Skinner, R. M. Boddey, and I. Fendrik (ed.), Nitrogen fixation with non-legumes. Kluwer Academic Publishers, Dordrecht, The Netherlands.

10. Seldin, L. 1992. Primary characterization of the bacteriophage BA-4 from a nitrogen-fixing Bacillus azotofixans strain. Microbios 71:167-177.

11. Smith, L. D. S., and E. P. Cato. 1974. Clostridium durum, sp. nov., the predominant organism in a sediment core from the Black Sea. Can. J. Microbiol. 20:1393-1397. 